\title{
DOWNSIZING EFFECTS ON PERSONNEL: THE CASE OF LAYOFF SURVIVORS IN U.S. NEWSPAPERS
}

\author{
Scott Reinardy \\ University of Kansas
}

\begin{abstract}
Lewin's (1947) organizational development theory says that after an organization reorganizes and downsizes, it "refreezes" to prechange comfort levels. This study of 2,159 newspaper layoff survivors indicates they perceive that refreezing at this time would be problematic because it would result in a journalism of mediocrity, more focused on quantity rather than quality. In light of previous research, the reduction of newsroom staff also alters the product attributes. In this case it may perpetuate the downward spiral of lost circulation and advertising revenue. The results indicate that for those employees experiencing a decline in trust, morale, satisfaction and commitment, newspapers are creating production-line journalism that is seen as void of purpose and function.
\end{abstract}

KEY WORDS: downsizing, layoff survivors, work quality, satisfaction, newspapers

Company reorganizations, particularly those involving significant downsizing, affect employees who are laid off but also those who remain with the company. Large-scale layoffs in recent years in the U.S. newspaper industry present an opportunity to study the effects of the layoffs on survivors' perceptions of how it has affected their work, their job satisfaction, and their employers.

For those in the newspaper industry, the headlines in the past three years have been grim. "Gannett downsizing claims 1,770 newspaper jobs;" "Los Angeles Times to cut 150 newsroom jobs, reduce pages;" "Hearst's San Antonio Express-News cuts 75 newsroom positions;" "New York Times to eliminate 100 newsroom jobs this year" (Poynter, 2010). And the Gannett Company, the largest newspaper group in the United States, might be emblematic of industry downsizing. When Gannett began the new millennium, it employed 53,400 workers. At the start of 2010, that

Copyright $\odot 2010$ Journal of Media Business Studies. Scott Reinhardy, "Downsizing Effects on Personnel: The Case of Layoff Survivors in U.S. Newspapers," 7(4):1-19 (2010). 
number was about 39,000 (Gannett blog, 2010). It's uncertain how many of the buyouts, layoffs and retirements included newsroom employees.

Although it's difficult to pinpoint a specific number of newspaper newsroom job losses, the annual State of the News Media 2010 report estimates that more than 13,000 full-time journalism jobs have been lost since 2006 (Edmonds, 2010). In the past three years, newspapers have bought out, laid off and diminished their editorial staffs by about $25 \%$ (Edmonds, 2010). In 2009, more than 40\% of daily newspapers (584) implemented layoffs (Smith, 2009). Since 2006, advertising revenue has declined 43\%, circulation dropped 16.9\% (Edmonds, 2010), and 143 newspapers stopped publishing print editions in 2009 (Smith, 2010). At about 41,500, the number of newspaper journalists has not been this low since the mid-1970s.

With an ongoing recession, more newsroom cuts may be forthcoming, although some firms are beginning to report some improvements in advertising revenues. According to the VSS Communications Industry Forecast 2009-2013, print advertising spending declined 16\% from 2007 to 2008 (Stevenson, 2009). In light of the reductions in national, retail and classified advertising, daily newspaper spending declined $14.6 \%$ in 2008 , and was projected to decrease by an additional $16.3 \%$ in 2009 .

In 2009, two long-standing newspapers-secondary papers in their markets--were shuttered when the Rocky Mountain News and the Seattle Post-Intelligencer stopped publication. The P-I continues in an online-only version. Some newspaper companies filed for bankruptcy protection (Philadelphia Newspapers, Minneapolis Star-Tribune, The Tribune Co., The Journal Register Co.), and are now emerging from bankruptcy under reorganization plans.

The newspaper industry is being affected by long-term trends in declining audience use and by dramatic short-term effects from the recession caused by the sub-prime mortgage crisis. Stevenson (2009) writes, "Newspapers will be more severely impacted by the current recession, and endure prolonged effects, due to changes in both advertiser and consumer behaviors and other negative trends" (p. 186).

Compounding the issue is the ongoing struggle to transition from a paper product to an electronic one without a business model to financially sustain the conversion. Stevenson (2009) reports that digital advertising decreased $1.6 \%$ in 2008 after four straight years of growth that averaged $27.4 \%$. Still, online advertising accounts for only $10 \%$ of total newspaper advertising with $90 \%$ still reliant upon the print edition (Edmonds, 2010). Stevenson said publishers will continue to experiment with business models for the online product but spending on the digital newspaper was projected to decline $4.3 \%$ in 2009 (Stevenson, 2009).

In light of dwindling readership, diminished advertising revenue and the proliferation of the Internet, during the past decade there has been a mandate for change in the newspaper industry (Gade, 2008; Gade, 2004; McGuire, 1994). Newspapers made attempts to become more "readeroriented, market-driven and technologically savvy," while asking 
reporters, editors and managers to accept new roles and responsibilities (Gade, 2008, p. 371). How people learn to develop and adjust during times of change is at the heart of organizational development theory. As newspapers attempted to adjust to economic and technological challenges, newsrooms were sideswiped by extensive layoffs. Economic losses are immediately tangible and relatively easy to measure so managers have maintained newspaper profitability by layoffs and reducing the number of editions and sections. In 2009, for example, the average return for newspapers was $13 \%$, three times the average for other industries, but about half what it had been before the recession (IPA, 2010). Because of organizational complexities, determining the direct effect of personnel losses is more difficult.

The purpose of this study is to examine the organizational development of newspaper newsrooms following substantial job losses. The research will study layoff survivors and their perceptions of organizational trust, organizational morale, employee coping and job commitment, and their affect on job satisfaction. Previous research has demonstrated that organizational downsizing is associated with declines in organizational commitment (Wiesner, Vermeulen \& Littler, 1999; Armstrong-Stassen, 1998), organizational morale (Wiesner et al., 1999; Cameron, Freeman \& Mishra, 1993), and organizational trust (Armstrong-Stassen, 1998). For managers, these issues can be toxic to the organization, particularly in terms of quality and quantity of work and turnover intentions.

Producing good journalism is the stock-and-trade of newspapers. Previous research has shown that investment in the newsroom is associated with perceptions of producing quality journalism, enhances circulation and, in turn, creates more advertising revenue (Rosenstiel \& Mitchell, 2004; Meyer 2004). When newsroom investment diminishes, and layoff survivors are asked to absorb the additional workload, quality is likely to change. With cuts occurring at newspapers throughout the nation, this study can provide insight into the emotional and behavioral state of those left to reconstruct journalism in their newsroom. That insight can assist managers in developing strategies to regain trust, build morale, generate organizational commitment, and improve job satisfaction, which in turn will lead to a higher quality of journalism.

\section{LITERATURE REVIEW}

In the 1980s, the Brockner et al. studies $(1985,1986)$ established that layoffs can create anxiety, remorse, guilt, and even anger for the survivors. Additional research has shown that survivors are predisposed to low morale, job dissatisfaction and reduced productivity, particularly among those who place a great deal of self-esteem and a sense of relevance into a company (Noer, 1993). There's further evidence that long-term consequences from survivor's syndrome can persist and worsen, which further exacerbate problems in the organization (Noer, 1993; Woodward, 
Shannon, Cunningham, McIntosh, Lendrum, Rosenbloom, \& Brown, 1999). In essence, workers believe if they do good work and are dedicated to the organization, they will be treated fairly. When the organization fails them, a trust is lost and what workers believe is fair treatment is counterintuitive to their perceptions of the organization's actions (Lees \& Taylor, 2004). Additionally, repeated job cuts can lead to a loss of morale, and undermine any recovery the survivors might have established (Wiesner et al., 1999). Noer (1993) writes: "Layoff survivor sickness is a serious, pervasive, and underestimated problem" (p. 211).

Wiesner et al. (1999) set out to create an operational definition of survivor syndrome and included six key variables: morale, staff commitment, perceived promotional opportunities, motivation, job dissatisfaction, and concern about job security. Of the six variables, morale (75.4\% of the cases), commitment (68.8) and motivation (70\%) decreased as job insecurity rose (80\%). Also, Wiesner et al. established that the depth of a single job cut is not as detrimental as multiple job reductions. They write: "Survivor syndrome outcomes are intensified or modified by the depth of the workforce reductions ('severity'), time pressure ('forewarning information' and 'clarity') and the frequency of downsizing" (p. 401).

As layoffs occur, particularly multiple layoffs, employees' commitment to an organization is challenged. Research has shown that individuals develop a psychological attachment to an organization that bonds individuals and the organization (O'Reilly \& Chatman, 1986). Organizational attachment is developed through psychological identification (Bowlby, 1982; Sanford, 1955; Stoke, 1950; Tolman, 1943). Similarities in attitudes, values and goals between the individual and organization are created and become a part of the cognitive response of the individual (Kagan, 1958). Building on Kelman's (1958) work, O'Reilly and Chatman (1986) set out to develop a measurement for organizational commitment that included such issues as compliance (which occurs when behaviors are adopted not out of shared beliefs but to gain rewards), identification (an individual feels proud to be part of the organization) and internalization (individual and the organization's values are the same). They discovered that identification and internalization of an organization were strongly associated with pro-social behaviors and negatively linked to turnover. O'Reilly and Chatman (1986) write: “Critical voluntary behaviors that are not specified by job descriptions are largely a function of identification and internalization rather than instrumental involvement" (p. 497). The authors said that while new employees operate under compliance, as tenure in an organization increases, workers appreciate organizational goals and values and pride develops.

In his review of 27 studies of layoff survivors' commitment, Grubb (2006) specifically examined organizational justice and its association with commitment. He focused on two aspects of justice: procedural (perceived fairness of the layoff process) and interactional (the treatment-dignity and respect-the individual receives from the person in the organization delivering the layoff news). Grubb reported that procedural justice (.34) 
was more highly correlated to commitment than interactional justice (.28), but together the two had the highest correlation to commitment (.52). Grubb writes: "Given the scarcity of organizational resources in times of a layoff, it is important that employers recognize the increased assuaging effect that the interpersonal treatment of layoff survivors can have on survivors' organizational commitment" (p. 526).

Coping, stress, job insecurity, organizational commitment, morale, and job satisfaction take on different dimensions when multiple layoffs occur. Moore, Grunberg and Greenberg (2006) identified the long-term impact of layoffs among survivors. They reported that even five years later issues concerning job security and stress were prevalent among survivors. Moore et al. write: "Our findings illustrate rather clearly that the average worker is not growing inured to working in a chronically tenuous and everchanging work environment" (p. 326).

Kurt Lewin (1947) was one of the first to develop a model under the premise of organizational development theory. His "unfreezing, change, refreezing" process is based on the notion that an organization needs to prepare for change, implement change, and create acceptance of the change in order to return to pre-change comfort levels. At several U.S. newspapers, the first two steps of Lewin's model have occurred. Cuts have been implemented, followed by a short freezing period that was followed by more cuts. So the continued uncertainty of more staff reductions has not allowed for a "refreezing" or any comfort level to occur.

Lewin's ideologies of organizational development hold up in principle but adaptations and modifications have been plenty. For instance, Bergquist (1993) suggests that a majority of organizational theorists have framed organizations as pendulum-swinging apparatuses that emphasize "simplicity in motion" and stability. During chaotic times organizations seek balance by returning to their preceding form and function. For the newspaper industry, that is no longer possible. Between technological transformations and diminished personnel, going back is not an option. Bergquist says that was true for other U.S. companies in the 1980s and early 1990s. He said the organization was more comparable to a liquid "poised on the edge of order and chaos" (p. 9). Bergquist wrote that the fluid system incorporates elements of stability and change, particularly along the edges. Gade, explaining Bergquist, (2004) writes: "It is these places on the 'edge' where innovation occurs and where organizational traits such as mission, communication, and leadership become integral to success" (p. 17).

As leaders attempt to direct organizational change, rank-and-file employees cope with the changes. Lazarus and Folkman (1984) said coping is situation specific defined as "constantly changing cognitive and behavioral efforts to manage specific external and/or internal demands that are appraised as taxing or exceeding the resources of the person" (p. 141). According to Lazarus and Folkman, coping with a situation serves two purposes: problem-focused coping-managing or altering the situation; and emotion-focused coping - efforts to regulate emotional responses to a 
problem. With that in mind, Lazarus and Folkman developed a selfreported scale to measure coping. They write: "We must identify the multiple demands in a stressful transaction and assess coping with respect to those demands and how they change over time" (p. 317).

Taking a cue from Lazarus and Folkman, Latack (1986) developed two coping categories: control (aggressive, take charge approach) and escape (issue avoidance). Latack said when individuals are uncertain in their roles, stress increases and control decreases. She reported that employees embracing a control coping strategy are "less likely to report job-related anxiety, job dissatisfaction and to leave the organization" (p. 383). Those who incorporate an escape-coping strategy are apt to experience more emotional distress.

The residual affects of dramatic organizational renovations ripple outward from those making the alterations to those most impacted by the change. As rank-and-file employees are provided the charge of implementing change, there can be a disconnect between what is working and what is not (Gade, 2004). Gade concludes that while management "believes" it has managed the change process, "rank-and-file... feel more victims of change than participants in it" (p. 45). He said morale was low, and declining, and that "rank-and-file feel organizational development efforts are focused on creating a more dominant marketing culture, often at the expense of journalistic norms" (pp. 45-46).

A 2004 Newspaper Research Journal special issue title, "Good Journalism, Good Business," examined the relationship between newsroom investment and quality journalism. In that issue, Rosenstiel and Mitchell write that investment in the newsroom has traditionally resulted in profitability but as circulation and advertising revenue slips, newspapers cut costs, i.e. newsroom staff. They write, "These cuts subtly reduce the quality and breadth of the paper. That, in turn, alienates readers, which then adds further pressure on circulation and advertising, which in turn leads to further cuts in costs, and the cycle spirals on" ( $p$. 87).

In that same NRJ edition, Picard (2004) assessed how commercialism has diminished journalistic quality and the newspaper's social mission. He says that business quality - providing value for the time and money spent by consumers - conflicts with journalistic value. He writes, "In journalism, however, quality is not merely a question of increasing the value of a product to consumers but is a central element in achieving the social, political and cultural goals asserted for journalism in democratic societies" (p. 61). Picard also says that sacrificing short-term profits for long-term journalistic quality would maximize the value of the newspaper. He concludes that newspaper leaders have proceeded down a "highway of commercialism" void of speed limits or even an obvious destination. Picard writes:

They have now reached a fork in the highway. One road continues down the path of unrestricted commercialism and unbridled corporate 
self interest. The other has limits set by the needs of quality, public service and responsibilities that extend beyond the shareholders (p. $64)$.

In "The Vanishing Newspaper," Philip Meyer (2009) initiates a frontal assault on the failed business model of supplementing profits at the expense of product quality. He writes, "The accountants appear to be guiding the transformation without much thought about the end product. If they continue to slash and burn their existing businesses, all they will end up with are slashed, burned, obsolete businesses" (p. 3). Early on, Meyer outlines how newspapers began cutting staff in the early 1990s to maintain high levels of profitability, readership began to decline. He said newspapers' influence in their communities also declined as newsroom resources diminished.

Fundamentally, journalists have recognized the conflict between profitability and resources to produce high quality journalism. In a Columbia Journalism Review special edition, Baker (2001) discussed the correlation between morale and maintaining a happy newsroom. St. Petersburg Times journalists placed profitability second to quality journalism while working in a positive newsroom environment. Baker said it made journalism "a joyful and rewarding profession" (p. 54).

In his 2006 study, Beam specifically examined the correlation between job satisfaction, and employee goals and priorities. Less satisfied journalists tended to work in organizations that were profit-oriented while more satisfied journalists worked for organization where management valued good journalism. Beam writes, "The most-satisfied journalists perceive a great deal of autonomy in their work and influence in the newsroom, and feel they are working for an organization doing a good job informing the public" (p. 182).

During this transformational period in American newspapers, reorganizing with fewer employees would be expected to have a substantial impact on newsroom culture. Expectations of production quality and quantity are sure to change, particularly during the economic downturn. Journalists are confronted with not only an economic recession but the longer term readership recession as well. Previous research has established the emotional and psychological implications for layoff survivors. This study will add to the previous work by examining tangential issues that contribute to a news worker's perceptions of the organization. Although it's difficult to economically quantify the impact of employee trust and morale on an organization, previous research suggests that during times of change work quantity and quality can diminish, and intentions to leave the organization increase. The results of this study will identify issues affecting layoff survivors, which will allow managers to develop strategies to address or prevent undesirable outcomes.

Through the prism of organizational development theory, perceptions of organizational trust and morale among layoff survivors will be examined. Journalists will also provide insight into how they are coping 
with the changes, as well as how committed they are to their jobs. Building on previous research, this study will examine the following hypothesis:

RQ1: What is the correlation between control coping and organizational trust, morale, organizational commitment, and job satisfaction of newspaper newsroom layoff survivors?

H1: Organizational commitment identification and control coping are significant predictors of trust among newspaper newsroom layoff survivors.

If layoff survivors feel a sense of identification with the organization, it is expected they will feel more control in coping with the dramatic newsroom changes. Individuals develop psychological attachments to organizations (O'Really \& Chatman, 1986; Bowlby, 1982), and that creates somewhat monolithic attitudes and goals. Commitment identification is prevalent when an individual feels proud to be part of the organization, and respects the organization's values and achievements, but does not personally adopt those values and achievements (Kelman, 1958). During the tumultuous newsroom cuts, identification might provide control coping mechanisms for employees. It may be giving them a sense of control if they believe their association is closely linked to the organization. Identification combined with control is expected to enhance trust in the organization.

H2: Organizational trust and morale are significant predictors of organizational commitment identification among newspaper newsroom layoff survivors.

In light of the work of Kelman (1958), and O'Reilly and Chatman (1986), it would stand to reason that the trust and morale of layoff survivors would be predictors of organizational commitment identification, which is established under the premise that an employee is proud to be a part of the organization. Identification has also been linked with pro-social behavior and low turnover intentions (O'Reilly \& Chatman, 1986).

H3: Morale, commitment identification, trust and control coping are significant predictors of job satisfaction among newspaper newsroom layoff survivors.

H4: Journalists with higher levels of job satisfaction will have significantly higher levels of morale, trust, commitment ID and control coping than journalists with lower levels of job satisfaction. 


\section{METHOD}

Utilizing previously established measurements, a 75-question survey was constructed examining organizational trust, organizational morale, employee coping, job commitment and job satisfaction. The first section of the four-section survey included questions about organizational trust, followed by a section inquiring about job commitment, morale and satisfaction. Section three asked about coping strategies and included some additional questions concerning work habits. The final section requested demographic information.

The "Papercuts" Web site, which is dedicated to tracking newspaper cuts (Smith, 2009), provided a list of daily newspapers that had experienced layoffs, buyouts and other job reductions. Newspapers that experienced cuts from Jan. 1, 2008, through May 31, 2009, were included in this study. A database of newsroom workers' e-mail was constructed by individually checking each newspaper's Web site. The list of e-mails included news clerks, reporters, news editors, copy editors, photographers, graphic designers, online reporters, online editors, columnists, managing editors and executive editors.

The 139 newspapers in this study represented all geographic regions of the United States and all circulation sizes from less than 5,000 to more than 1 million. E-mails of 9,629 journalists were collected. In July 2009, journalists received an e-mail invitation to participate in the survey. The e-mail explained the purpose of the study and included a SurveyMonkey link to the questionnaire. Journalists were invited to participate on a voluntary basis, and were assured that their responses would be confidential. A reminder e-mail was sent in August 2009. The survey remained available for one month.

\section{Measurements}

Perceived organizational trust: For this study, the perceived organizational trust scale developed by Ashford, Lee and Bobko (1989) was used. The five-question measurement asked respondents to answer on a five-point Likert-like scale ( $1=$ strongly disagree; $5=$ strongly agree) to statements such as "I trust this organization to look out for my best interests" and "I believe in top management of this organization." For this study, "organization" was replaced with "newspaper." Cronbach's alpha in this study is .85 .

Organizational commitment: This study used a condensed version of O'Reilly and Chatman's (1986) commitment scale, selecting four items from the "identification" scale and three items from the "compliance" area. The seven-point Likert-like scale ( $1=$ strongly disagree; $7=$ strongly agree) asked participants to respond to such questions as "What this organization stands for is important to me," and "My private views about this organization are different from those I express publicly." Once again, "newspaper" was substituted for "organization." Cronbach's alpha for 
commitment identification in this study is .81 but for commitment compliance it is .05, which is below acceptable levels. Therefore, the commitment compliance variable is not examined in this study.

Perceived organizational morale: Scott (1967) developed the perceived organizational morale instrument. In this study, the Scott scale was supplemented with items from the Armstrong-Stassen (1998) instrument. The general question asked, "How do you feel about your job," and then included subcategories such as "enthusiastic" to "indifferent," which in essence provided a seven-point scale. For this study, the scale was modified for simplicity purposes. The five-question area posed questions such as "How enthusiastic or indifferent do you feel about your job?" The seven-point scale ranged from " 1 extremely indifferent" to "7 extremely enthusiastic." The other questions included such items as "encouraged/discouraged" and "frustrated/motivated." Cronbach's alpha in this study is .88 .

Coping: A modified version of Latack's (1986) coping scales was used in this study, which included two areas: control coping (eight questions) and escape coping (five questions). The original measurement had a total of 28 items. A five-point Likert-like scale was used $(1=$ hardly ever do this; $5=$ almost always do this). Cronbach's alpha for control coping was .80 in this study, but the alpha for escape coping was .48, which generally isn't considered an acceptable level. So, escape coping will not be examined in this study.

Overall Job Satisfaction: Cammann, Fichman, Jenkins and Klesh's (1983) Michigan Organizational Assessment Questionnaire included a subcategory to measure job satisfaction. The three-question instrument included such items as "All in all, I am satisfied with my job" and "In general, I don't like my job" (reverse coded). Participants were asked to respond on a seven-point Likert-like scale (1 = strongly disagree; $7=$ strongly agree). Cronbach's alpha in this study was .88 .

\section{FINDINGS}

Because there were 539 "dead" e-mail addresses, the sample of 9,629 journalists was reduced to 9,090 . With 2,159 journalists completing the survey, this study had a response rate of about $24 \%$, which is comparable to other online surveys (Reinardy, 2009; Asch, as cited in Schonlau, Fricker \& Elliot, 2002). Mean substitution replaced missing values in the dataset, but no more than 5\% of any variable was replaced.

Respondents averaged 44 years of age with 20 years of professional experience, including 13 years at their current newspaper. They were $61 \%$ male, $89 \%$ Caucasian and averaged 44 hours of work per week. The average circulation of the newspapers was about 244,000. Reporters made 
up the largest group (40.3\%), followed by managers (13.6\%), news editors (13.4\%), copy editors (9.6\%) and photographers (7.3\%).

RQ1 asks to examine the correlations between the variables control coping, organizational trust, morale, organizational commitment (identification) and job satisfaction of newspaper newsroom layoff survivors. Organizational trust has a moderate, positive and significant correlation to morale (.56), job satisfaction (.51) and commitment identification (.48), and a small correlation to control coping (.20). Job satisfaction is highly correlated with morale (.85) and moderately associated with commitment identification (.59) and control coping (.37). Control coping has moderate, significant correlations to morale (.35) and commitment identification (.35). Morale and commitment identification were also significantly correlated (.53). To summarize, as any of these variables increase, there are positive increases in the other variables as well (see Table 1).

Table 1. Correlations for Variables Used in This Study

\begin{tabular}{|c|c|c|c|c|c|}
\hline & $\begin{array}{c}\text { Organizational } \\
\text { trust }\end{array}$ & $\begin{array}{l}\text { Org. Commit } \\
\text { Identification }\end{array}$ & Morale & $\begin{array}{l}\text { Control } \\
\text { Coping }\end{array}$ & $\begin{array}{c}\text { Job } \\
\text { Satisfaction }\end{array}$ \\
\hline $\begin{array}{l}\text { Organizational } \\
\text { trust } \\
\mathrm{N}=2159\end{array}$ & 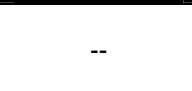 & & & & \\
\hline $\begin{array}{l}\text { Org. Commit } \\
\text { Identification } \\
\mathrm{N}=2159\end{array}$ & $.480^{* *}$ & -- & & & \\
\hline $\begin{array}{l}\text { Morale } \\
\mathrm{N}=2159\end{array}$ & $.563^{\star *}$ & $.534^{\star \star}$ & & & \\
\hline $\begin{array}{l}\text { Control } \\
\text { Coping } \\
N=2159\end{array}$ & $.200 * \star$ & $.348^{* *}$ & $.349 * *$ & -- & \\
\hline $\begin{array}{l}\text { Job } \\
\text { Satisfaction } \\
N=2159\end{array}$ & $.513^{\star *}$ & $.586^{\star *}$ & $.845^{\star \star}$ & $.366^{\star \star}$ & -- \\
\hline
\end{tabular}

Multiple linear regression analysis was utilized in examining hypotheses 1, 2, and 3 in this study. H1 states that commitment identification and control coping are significant predictors of trust among newspaper newsroom layoff survivors. When trust was the dependent variable, commitment ID and control coping accounted for about $23 \%$ of the variance (adjusted $\mathrm{r}$-square $=23.1), \mathrm{F}(2,2,156)=276.35, \mathrm{p}<.001$. Commitment ID $[B=.463, \mathrm{t}(2,2,156)=21.24, \mathrm{p}<.001]$ was a positive and significant predictor of trust, as was control coping $[B=.048, \mathrm{t}(2,2,156)=$ $2.20, \mathrm{p}<.05]$. Therefore, H1 was supported.

H2 states that organizational trust and morale are significant predictors of organizational commitment identification among newspaper newsroom layoff survivors. When commitment ID was the dependent variable, trust and morale accounted for about $33 \%$ of the variance (adjusted r-square $=.333), \mathrm{F}(2,2,156)=494.54, \mathrm{p}<.001$. Trust $[B=.265$, 
$\mathrm{t}(2,2,156)=11.94, \mathrm{p}<.001]$ was a positive and significant predictor of commitment ID, as was morale $[B=.386, \mathrm{t}(\mathrm{t}, 2,156)=17.37, \mathrm{p}<.001] . \mathrm{H} 2$ was supported.

H3 said morale, commitment ID, trust and control coping are significant predictors of job satisfaction among newspaper newsroom layoff survivors. With job satisfaction as the dependent variable, morale, commitment ID, trust and control coping accounted for about $75 \%$ of the variance (adjusted $\mathrm{r}$-square $=.74 .5), \mathrm{F}(4,2,154)=1297.01, \mathrm{p}<.001$. Morale $[B=.734, \mathrm{t}(4,2,154)=46.03, \mathrm{p}<.001]$, commitment ID $[B=.184$, $\mathrm{t}(4,2,154)=12.27, \mathrm{p}<.001]$ and control coping $[B=.044, \mathrm{t}(4,2,154)=3.37$, $\mathrm{p}=.001]$ were positive and significant predictors of job satisfaction. Trust was not a significant predictor of job satisfaction in this model. H3 was partially supported.

H4 said that journalists with higher levels of job satisfaction will have significantly higher levels of morale, trust, commitment ID and control coping than journalists with lower levels of job satisfaction. Cammann et al.'s Michigan Organizational Assessment Questionnaire does not establish "high" or "low" levels of job satisfaction but their instrument does provide comparatives to other professions, which include government employees and civil service employees (see Table 2). In this study, out of a possible 21, the mean score was 15.2. Other studies have reported higher scores among newspapers journalists (15.7) (Reinardy, 2009), sports editors (16.2) (Reinardy, 2007) and sportscasters (17.1) (Reinardy, 2009).

A division between "high" levels of satisfaction and "low" was determined by dividing the sample in half with 1,039 scoring a 17 or higher and 1,045 scoring a 16 or lower. Independent sample t-test was conducted to compare the groups. The results indicate significant differences between the two groups and morale $(p<.001)$, trust $(p<.001)$, commitment ID $(p<.001)$ and control coping $(p<.001)$. Those with higher levels of job satisfaction had significantly higher levels on the four variables. H4 was supported.

Additionally, among those with high job satisfaction levels, younger (35 and younger), less experienced journalists (1 to 5 years) working at smaller newspapers (200,000 circulation or less) had significantly higher levels of trust than older (36 or older), more experienced (11 to 15 years and 21-25 years) journalists working at larger newspapers (500,000 circulation or more). When examining age, experience and newspapers size, there were no differences in morale, commitment ID or control coping.

Incidentally, those who specifically listed "manager" as their job title had higher levels of satisfaction (16.2), as well as morale, trust, organizational ID and control coping. There were few differences between other job groups and the variables. 
Table 2. Comparing Job Satisfaction Levels among Professions

\begin{tabular}{|l|c|}
\hline \multicolumn{1}{|c|}{} & Satisfaction Score \\
\hline Sportscasters & 17.4 \\
\hline Sports editors & 16.2 \\
\hline Government employees & 16.1 \\
\hline Newspaper journalists (2009) & 15.7 \\
\hline Newspaper journalists (2010) & $\mathbf{1 5 . 2}$ \\
\hline State service employees & 14.4 \\
\hline Different occupations & 14.0 \\
\hline
\end{tabular}

* Cammann, et al. (1983) did not create a legend that determines

high or low levels of job satisfaction based upon raw scores. This

is only a comparative.

** Bold indicates this study

\section{DISCUSSION}

In an effort to determine if the work of journalists has changed, additional survey questions asked if newspaper journalists worked differently, and if so, how. Sixty-eight percent said they worked differently. The "how so" question was open-ended and included 1,134 responses. The word "more" was cited 981 times by the respondents. "More work" was mentioned 122, more work specifically due to layoffs was written 132 times, and more work because of the Web was listed 83 times. "More responsibility" was written 69 times. Alternatively, the word "less" was cited 313 times and included issues such as less time, support, planning, rewards, money/pay and "more with less." One respondent said, "We are expected to produce more with less support from our supervisors who have taken the attitude that we should be happy to just have a job."

With the reduction in staff, and expansion into the multimedia marketplace, doing more with less was a binary complication for many journalists. The responses indicated that newspaper journalists are not only taking on additional work, but working in areas where they lack expertise. One journalist said, "I am now doing parts of 5 different people's jobs. Therefore, I've had to drop parts of the job that I actually got into this field to do, things that I like to do." Speaking for many, one wrote, "i'm doing a half-assed job of what 3 people used to be responsible for."

Perhaps not surprisingly, additional job responsibilities led to the inevitable perception of reduced work quality. For those who said they now work differently, reduced quality of work was specifically cited 196 times. One copy editor said, "I am forced to emphasize quantity of work over quality. In other words, I feel more like a production worker than a copy editor." Reduced quality was presented as more errors, less fact checking, fewer sources cited in stories and less specialized coverage. The reduction in quality is also taxing the committed journalist, who is working more hours and doing less desirable work. One person wrote, "I now do crummy work and don't feel ashamed in saying so. I've eliminated 'pride' from my work routine." Another wrote, "No one cares about content, why should I?" 
Several journalists said their newspaper has lowered standards, paying less attention to details, using fewer sources and accepting stories that would be considered "low-hanging fruit" in the past. Depth reporting and writing, enterprise stories and investigative journalism have fallen to the wayside for a great number of journalists in this study. One journalist wrote, "I shy away from the controversial story unless I can work on it quietly without my editor knowing. If my editor knows, he will rush me, compromise the quality of reporting."

In "The Vanishing Newspaper," Meyer (2009) cites Harvard professor Michael E. Porter's "harvesting market position." Harvesting occurs when a stagnant industry raises prices and lowers quality in an effort to harvest the market position. The industry relies on brand loyalty rather than substance to continue to attract long-standing customers. Because harvesting involves a non-renewable, "take-the-money-and-run" strategy, it cannot sustain the industry. Even brand loyalists depart. Meyer contends that during this decade newspaper managers appeared to be harvesting but not with an end-game mentality. Instead the harvest is occurring as newspapers attempted to transfer from one delivery system (newspaper) to another (online). Meyer writes, "Such a transfer requires investment, of course, and the problem was to generate the resources without damaging the brand, in order to engage in costly experiments with new forms of media" (p. 14).

Compounding the problem was the economic recession. During the process of adaptive harvesting, the industry saw advertising revenue collapse, dwindling readership, and the advent of emerging competitive markets primarily generated via the Internet. What wasn't being internally harvested was being culled by outside competition. Valued information was being produced by other sources. Those sources were not only considered reliable but plentiful.

The journalists here indicated that personnel and product quality is being harvested. For many in this study their newspapers continue their commitment to expansive coverage at the price of quality coverage. Byline quotas motivate reporters to pluck the easier, less intense stories, even though they acknowledge it isn't the journalism they prefer. One journalist wrote, "I can definitely tell I'm 'mailing it in' on the more mundane stories, whereas in the past, I would've tried harder." Another said, "Doesn't take a math wizard to realize you are cutting corners somewhere. Maybe it's only having two sources where you would have had three or four, but you have to cut back somewhere just to make the deadlines."

The journalists with high levels of job satisfaction (17 or higher) were also concerned about quality but appeared more optimistic than those with lower satisfaction levels. They discussed having autonomy to be more selective in story assignments, learning new tools to feed the Web product, and seemed enthused about the new direction their newspapers were taking. One 30-year newspaper veteran said, "We are working on ways to work smarter, to decide what we place emphasis on and invest time in." 
It cannot be ignored that several highly satisfied journalists admitted to working harder because a renewed appreciation for their jobs. It also could be interpreted as fear of losing their jobs. Several discussed improving their value to the newspaper, and demonstrating initiative to work more and accept new duties.

\section{CONCLUSIONS}

The purpose of this study was to examine the organizational development of newspaper newsrooms following substantial job losses. Understanding how remaining employees adapt to organizational changes is essential in sustaining a high quality of work, employees' commitment, morale, trust and job satisfaction.

Journalists in this study who demonstrated high degrees of job satisfaction also had significantly higher levels of trust, morale, commitment ID and control coping than those with lower satisfaction levels. Interpreting those results can be difficult. Open-ended comments suggest a diminished dedication and enjoyment among journalists and their work. While this study reports associations between the variables and job satisfaction it does not necessarily indicate that there are high degrees of trust or morale occurring at newspapers.

According to Brockner, redefining the old job and developing new job opportunities is central to the well-being of employees during the organizational retooling. In light of the Internet, it certainly can be argued that the job of a newspaper journalist has changed dramatically, providing new opportunities to those willing to adapt. The opened-ended comments suggest that a multitude of newspaper managers have encouraged Webbased opportunities. However, while encouraging online strategies it appears the old jobs have not been redefined. Instead, the new opportunities are tacked onto the old duties, resulting in an overworked newsroom that admittedly produces inferior work.

Organizational development theory examines how people learn and develop during a time of change. Lewin (1947) surmised organizational change occurs in a three-step process-"unfreezing, change, refreezing." Newspaper journalists have been subjected to the first two steps, but the third is an ongoing process. The "refreezing" may take some time and theoretically will not occur until the organization returns to the prechange comfort zone. The results of this study indicate that the refreezing might not occur anytime soon, particularly in light of additional cuts, shifting multi-media strategies and an unsustainable business model for an online product. Also, the comments indicate that journalists perceive refreezing at this time would result in mediocre journalism more focused on quantity rather than quality.

If newspapers fail to adapt, they take the risk of falling into the cycle established by Rosenstiel and Mitchell (2004). They proposed that disinvesting in newspapers will lead to circulation and advertising 
declines, which in turn will lead to more disinvestments. This cycle appears to have taken root at several newspapers where multiple layoffs and buyouts have occurred during the past two years. Conversely, Rosenstiel and Mitchell determined that investment in the newsroom leads to long-term growth and profitability. They write, "On the other side, if a paper does not invest, it is likely to do significantly less well over time."

In terms of this study, investment is not just bodies in the newsroom. Investment includes maintaining the wellbeing of the news workers, developing trust in the organization, building morale and job satisfaction, which in turn will be reciprocated with commitment and a desire to produce quality work. Consistent with Beam's (2006) findings, this study suggestions that journalists are committed to quality-oriented journalism and less satisfied in profit-oriented organizations. If economic viability becomes a substitute for journalistic integrity, the newspaper will have neither profits nor a valued product.

Journalists who indicated they are satisfied with their jobs and continue producing quality journalism, said prioritizing the workload and autonomy were instrumental in establishing an enjoyable work environment. Even though the highly satisfied still complained of heavy workloads and additional responsibilities, they appeared invigorated by the new challenges, which included a variety of job duties and online work.

In retooling newsrooms, perhaps managers need to streamline coverage to match their workforce. With diminished resources and fewer journalists, being all things to all readers just isn't practical unless newspapers are willing to sacrifice quality. Reordering the journalistic ranks from being generalists to becoming specialists appears to be an appropriate action. The choice between producing a large quantity of mediocre stories, or fewer stories with greater quality, seems obvious. When the product loses its value in the marketplace, newspapers will no longer have an audience or be relevant.

This study is not without limitations. Although e-mail invitations to complete the survey were directed to specific individuals, there is no absolute certainty who completed the survey. Also, disgruntled employees might be more inclined to complete a survey that examines morale and trust in an organization than those content in their work.

Layoff survivors are burdened with many emotional, psychological and physical issues. Along with anxiety, remorse, guilt and anger, there are the additional workload and job responsibilities. Newspaper newsrooms are undergoing unprecedented changes. Their survival is contingent on how well the remaining employees develop and adapt. Previous research has demonstrated that organizational downsizing is associated with declines in commitment (Wiesner, Vermeulen \& Littler, 1999; ArmstrongStassen, 1998), morale (Wiesner et al., 1999; Cameron, Freeman \& Mishra, 1993), and trust (Armstrong-Stassen, 1998). For managers, these issues can be toxic to an organization. If newspaper newsrooms continue to sacrifice quality for quantity, the morale, trust, commitment and job 
satisfaction of layoff survivors will continue to diminish. If that happens, organizations will be re-inventing themselves in ways they never imagined.

\section{REFERENCES}

Ashford, S.J., Lee, C., \& Bobko, P. (1989). Content, causes, and consequences of job insecurity: A theory-based measure and substantive test. Academy of Management Journal, 32(4), 803-829.

Armstrong-Stassen, M. (1998). Downsizing the federal government: A longitudinal study of managers' reactions. Canadian Journal of Administrative Sciences, 15(4), 310-321.

Baker, R. (2001). A happy newsroom, for Pete's sake. Columbia Journalism Review 40(3): 5457.

Beam, R.A. (2006). Organizational goals and priorities and the job satisfaction of U.S. Journalists. Journalism \& Mass Communication Quarterly 83(1): 169-185.

Bergquist, W. (1993). The postmodern organization: Mastering the art of irreversible change. San Francisco: Jossey-Bass.

Bowlby, J. (1982). Attachment. New York: Basic Books.

Brockner, J. (1992). Managing the effects of layoffs on survivors. California Management Review, 34(2), 9-24.

Brockner, J., Davey, J., \& Carter, C. (1985). Layoffs, self-esteem and survivor guilt: Motivational, affective, and attitudinal consequences. Organizational Behaviour and Human Decision Processes, 16, 229-44.

Brockner, J., Greenberg, J., Brockner, A., Bortz, J., Davy, J., \& Carter, C. (1986). Layoffs equity theory and work motivation: Further evidence for the impact of survivor guilt. Academy of Management Journal, 29, 373-84.

Cameron, K.S., Freeman, S.J., \& Mishra, A.K. (1993). Organizational downsizing. In G.P. Huber \& W.H. Glick (Eds.), Organizational change and redesign: Ideas and insights for improving performance (pp. 19-65). New York, NY: Oxford University Press.

Cammann, C., Fichman M.G., Jenkins, Jr., D. \& Klesh, J.R. (1983). Assessing the attitudes and perceptions of organizational members. In Seashore, S.E., Lawler III, E.E., Mirvis, P.H., \& Cammann, C. (Eds.), Assessing organizational change: A guide to methods, measures, practices. NY: John Wiley.

Edmonds, R. (2010). The State of the News Media 2010: An annual report on American journalism. Pew Project for Excellence in Journalism. Retrieved May 12, 2010, from: http://www.stateofthemedia.org/2010/newspapers_summary_essay.php.

Gade, P. (2004). Newspapers and organizational development: Management and journalists perceptions of newsroom cultural change. Journalism \& Mass Communication Monographs 6: Spring.

Gade, P. (2008). Journalism guardians in a time of great change: Newspaper editors' perceived influence in integrated news organizations. Journalism \& Mass Communication Quarterly, 85(2): 371-392. 
Gannett Blog (2010). In New Year, Gannett's workforce seen below 40K; outlook appears better--depending on economy. Retrieved May 12, 2010, from: http://gannettblog. blogspot.com/2009/01/in-new-year-gannetts-workforce-seen.html.

Grubb, W.L. (2006). Procedural justice and layoff survivors' commitment: A quantitative review. Psychological Reports, 99, 515-30.

Inland Press Association/International Newspaper Financial Executives (2010). Inland/INFE National Cost and Revenue Study. De Plains, IL: IPA/INFE.

Kagan, J. (1958). The concept of identification. Psychological Review, 65, 296-305.

Kelman, H.C. (1958). Compliance, identification, and internalization: Three processes of attitude change. Journal of Conflict Resolution, 2, 51-60.

Latack, J.C. (1986). Coping with job stress: Measures and future directions for scale development. Journal of Applied Psychology, 71(3), 377-85.

Lazarus, R.S., \& Folkman, S. (1984). Stress, appraisal, and coping. New York: Springer Publishing Company.

Lees, M., \& Taylor, G (2004). Mergers and the new workplace: The effects of a merger of two emergency departments on nursing staff. Journal of Health \& Human Services Administration, 26(4), 470-484.

Lewin, K. (1947). Frontiers in group dynamics: Concept, method and reality in social science: social equilibria and social change. Human Relations, 1 (June), 5-41.

McGuire, T. (1994). Sharing the excitement of newspaper change. ASNE Bulletin, October: 5.

Meyer, P. (2004). The influence model and newspaper business. Newspaper Research Journal, $25(1), 66-83$

Meyer, P. (2009). The vanishing newspaper: Saving journalism in the information age. Columbia, MO: University of Missouri Press.

Moore, S., Grunberg, L., \& Greenberg, E. (2006). Surviving repeated waves of organizational downsizing: The recency, duration, and order effects associated with different forms of layoff contact. Anxiety, Stress, and Coping, 19(3), 309-329.

Noer, D.M. (1993). Healing the Wounds: Overcoming the Trauma of Layoff and Revitalizing Downsizing Organizations. San Francisco: Jossey-Bass.

O'Reilly, C., \& Chatman, J. (1986). Organizational commitment and psychological attachment: The effects of compliance, identification, and internalization on prosocial behavior. Journal of Applied Psychology, 71(3), 492-99.

Poynter.org (2010). Search Results for 'newsroom cuts.' Retrieved May 12, 2010, from: http://www.poynter.org/search/results_article.asp?txt_searchText=newsroom+cuts\&txt_s earchScope $=$ all\&DGPCrPg $=1 \& D G P C r S r t=2 D$.

Picard, R.G. (2004). Commercialism and newspaper quality. Newspaper Research Journal, 25(1): 54-65.

Reinardy, S. (2007). Satisfaction vs. sacrifice: Sports editors assess the influence of life issues on job satisfaction. Journalism \& Mass Communication Quarterly, 84(1 Spring), 105121. 
Reinardy, S. (2009). Beyond satisfaction: Journalists doubt career intentions as organizational support diminishes and job satisfaction declines. Atlantic Journal of Communication, 17(3), 126-139.

Reinardy, S. (2010). Feeling the love: Sportscasters score big with job satisfaction. Paper accepted for presentation at the Broadcast Education Association conference, Las Vegas, April 2010.

Rosenstiel, T., \& Mitchell, A. (2004). The impact of investing in newsroom resources. Newspaper Research Journal, 25(1), 84-97.

Sanford, N. (1955). The dynamics of identification. Psychological Review, 62, 106-18.

Schonlau, M., Fricker Jr., R.D., \& Elliott, M.N. (2002). Conducting research survey via e-mail and the web. Santa Monica, Calif: Rand.

Scott, W.E., Jr. (1967). The development of semantic differential scales as measures of "morale." Personnel Psychology, 20, 179-198.

Smith, E. (2009). Papercuts: Newspaper buyouts and layoffs. Retrieved June 1, 2009, from http://graphicdesignr.net/papercuts/.

Stevenson, V.S. (2009). VSS: Communications industry forecast 2009-2013, 23 rd edition. New York: Veronis Shuler Stevenson.

Stoke, S. (1950). An inquiry into the concept of identification. Journal of Genetic Psychology, $76,163-89$

Tolman, E. (1943). Identification and the post-war world. Journal of Abnormal Social Psychology, 38, 141-48.

Wiesner, R., Vermeulen, L.P., \& Littler, C.R. (1999). Survivor syndrome: Effects on middle managers in South Africa. SAJEMS NS, 2(3), 390-406.

Woodward, C.A., Shannon, H.S., Cunningham, C., McIntosh, J., Lendrum, B., Rosenbloom, D., \& Brown, J. (1999). The impact of re-engineering and other cost reduction strategies on the staff of a large teaching hospital: A longitudinal study. Medical Care, 37(6), 55669 . 
Copyright of Journal of Media Business Studies is the property of Journal of Media Business Studies and its content may not be copied or emailed to multiple sites or posted to a listserv without the copyright holder's express written permission. However, users may print, download, or email articles for individual use. 